\title{
Discrimination? Protestantism and Jewish Christians in the State of Israel
}

\author{
Van Klinken, Gert J \\ Protestants Theologische Universiteit, Amsterdam \\ gjvanklinken@pthu.nl
}

\begin{abstract}
During the nineteenth and early twentieth century, Jewish mission became an established branch of Protestant mission in general. As the Jewish converts to Protestantism remained fairly few in numbers, these converts were expected to engage in missionary efforts too, a mong their fellow Jews. One of the results of the ensuing polarization was the exclusion of baptized Jews from the citizenship of the State of Israel, where they were considered traitors by a majority of society. This article argues that programmes for Jewish-Christian dialogue in the State of Israel came under pressure to bar the Jewish Christians from taking part, and explores the question whether the ensuing policies can be ranked as examples of discrimination against this group.
\end{abstract}

\section{Key words}

Israel, Jewish-Christian dialogue, mission, Jewish Christians

\section{Introduction}

"Founding fathers" of Protestantism, such as Luther and Calvin, like to stress Scripture rather than geography. The notion of a "Land of the Bible" does not belong to their dictionary. Palestine in the Reformation era was hard to reach, being governed by the Turks. The Ottoman administration made use of the millet-system. ${ }^{1}$ Recognized religious minorities or "millets" were allowed a measure of autonomy. For the system to work, it was not only important that the millets paid their taxes, but also that they would refrain from meddling in each other's affairs. At first, Protestants

1 Single: milla. 
had no part in this state of affairs: most of the Christian holy places were in the "custodia" of either the Roman-Catholics or the Greek-Orthodox, and sizeable Protestant communities were lacking. The general attitude towards the area reflected strong notions of Western superiority. Palestine, in the words of the Dutchman Jan Antonie Oostkamp (1778-1845) offered the impression of a wilderness, "under the predations of fiery Arabs and maladministrating Turks."2

By then, the effective power of the Porte in Constantinople was on the wane. Emerging powers like Great-Britain and Prussia introduced the novelty of a joint Protestant bishopric in 1841. The initiative fell apart in the eighties. By then, the Ottoman government was no longer able to enforce the millet-principle of non-interference. The London Society for Promoting Christianity amongst the Jews, the Edinburgh Medical Mission and the Swiss Basel Mission combined their missionary approach with health care and education. However, the focus on proselytizing cannot be regarded as a general feature of Protestantism in Palestine. Both the German Templars, an off-shoot from Pietism and Lutheranism in Schwaben and Württemberg, and the American Colony abstained from an overtly missionary approach. Instead, they both focussed on the build-up of a modern market economy.

A common trait is the interest in eschatology, rooted in $17^{\text {th }}$ century Puritanism. Sir Henry Finch had written The World's Great Restauration, or the Calling of the Jews, and with them of all the Nations and Kingdomes of the Earth, to the Faith of Christ in $1621^{3}$ George Stanley Faber, one of the founders of the London Society for Promoting Christianity amongst the Jews in 1809, authored a bestseller: A general and connected view of the prophecies, relative to the conversion, restauration, union and future glory of the Houses of Judah and Israel. Lord Anthony Ashley Cooper, seventh Earl of Shaftesbury, envisaged a "Jewish-Christian restauration in the Holy Land." The Australian George Gawler advocated a Jewish national state in Palestine, as an ally of Great-Britain against the forces of Islam. The

2 J.A. Oostkamp, De merkwaardigste Bijbelsche Land-en Zeereizen. Een leesboek voor de jeugd (Amsterdam: Beyerinck and Suringar, 1833), pp. 55-56.

3 Henry Finch, The World's Great Restauration. Cf. R.J. van Elderen, Toekomst voor Israël, pp. 133-143.

4 Shlomo Sand, The invention of the Land of Israel, p. 151. 
American novelist George Elliot (Mary Ann Evans) welcomed the prospect of a Jewish State in Palestine in her book Daniel Deronda (1876), though without the motive of conversion to Christianity. A cultural link sufficed. ${ }^{5}$

The Jewish Mission of the Free Church of Scotland applied the influences of both Faber and Gawler in the Tiberias Missionary Hospital (1885). Here, as in most Reformed churches, conversion of the Jews remained a paramount aim. A converting Jew confessed Christ as the only way to earn God's grace. He also confessed that the Jewish people had been in the wrong, all the ages since Christ appeared on earth. And, last but not least, the convert would do all that was in his or her power to convert other Jews and make them member of the Christian Church. In the eyes of the Jewish community (jishuv) in Palestine, this amounted to treason. Christian Jews were abhorred and shunned, far more than Christian Arabs by the Muslim majority in Palestine.

\section{Medical missions}

The millet-system was meant to keep religious and ethnic groups apart, not to provide them with a base from which they could launch a missionary offensive on the other segments of society, with the explicit aim of converting to one of the many versions of the Protestant faith. However, the sultan no longer had the effective power to prevent this. The tanzimatprogramme of modernisation depended on Western aid, especially in the field of education, finance and technology. When it came to the missions, results were very uneven. For given eschatological reasons, Protestants were mainly interested in the Jews. However most of the Palestinians who attended their schools and hospitals, and who in some cases converted to Protestantism, came from indigenous Greek-Orthodox stock. As a German visitor to Tiberias commented, the great majority of the Jews would have none of it: "The Rabbis placed all these labours under their curse." 6

The Muslims and Druze preferred a pragmatic attitude. In their case too there tended to be very few conversions, but they had no qualms about

5 On George Elliot and early Zionism: Martin Gilbert, Israel. A history (London: Harper Collins, 2008), p. 4.

6 E. Zickermann, “Evangelische Liebesarbeit,” p. 200. 
using Western hospitals and schools, even if run by the Missions. Yet, director David Watt Torrance (1862-1923) of the Tiberias hospital was in no doubt about the aim of his work: "In many insensible ways it prepared their minds (...) it was the forerunner and handmaid of the Christian evangelist". ${ }^{7}$

\section{In the State of Israel}

The war in 1948 changed everything. The UN partition plan was dropped. A majority of the Arab population was evicted from what became the State of Israel. Their homes and lands were taken over by European victims of the Holocaust and by Sephardi Jews from the Arab world. Protestants differed widely in their attitude towards the new-born State of Israel. But one thing was clear: the murder of six million Jews weighed heavily on the conscience of the churches in countries from which these Jews had been deported: First of all, Germany; but also the Netherlands. These churches were willing to help the survivors in their new-born State of Israel. They also tried to affirm that they had opposed Hitler's Endlösung, something that could only be achieved by seeking friendship and dialogue with the surviving Jews.

However, most of these survivors in Europe, after all they had been through, were not interested, to put it mildly. The Israeli government however, was more forthcoming. It was anxious to employ every possibly medical aid for the unprecedented influx of immigrants, most of them destitute. In the example of Tiberias, this meant recognition of the milla-status of the Scottish hospital, though it was clearly made understood that Jewish patients would not be subjected to missionary efforts against their wishes. The Scots doubted whether the continuation of the hospital made sense. They had lost their Arab patients and staff, the scope for evangelization would be limited. What reason could there be to go on?

The answer came from the Netherlands, where the Dutch Reformed Church (DRC) offered its cooperation: doctors, nurses, theologians. But, to the surprise of the Scots: no missionaries. The DRC had launched an ambitious programme of revitalizing Dutch Protestantism. One of the most striking

7 W.P. Livingstone, A Galilee doctor, p. 161. 
features was the Council for Church and Israel (CCI), founded by the DRC during the German occupation of the Netherlands. Jews and Calvinists, so was the idea, would meet as equals, in a "conversation" in which they would discuss Bible exegesis together. Of course, each partner would try to convince the other. The DRC had not given up hope that the Jews would accept Jesus as the Messiah. But the days of missionary monologue had ended.

These ideas were not well received by the Committee for Jewish Mission in Edinburgh. However, confronted by the alternatives of either closing the half-ruined hospital or accepting the DRC offer, the Scots opted for the latter. As it turned out, the two Protestant nationalities cooperated quite well in medical affairs, but never saw eye to eye in theology or politics.

The DRC had never asked the Dutch-Jewish community whether it was willing to engage in the proposed "conversation between Church and Israel". Most Holocaust survivors in the Netherlands clearly were not. If the DRC wanted to be welcomed by the Jews, then the chances looked brighter in the State of Israel that clearly was in need of help. As a result, the CCI presented itself as a staunch ally of the Jewish State. The result was a curious dichotomy: For the Scots Tiberias was an occupied city, for the Dutch a liberated city. To restore the balance, the Reformed Churches in the Netherlands (RCN) became the next partner in the Tiberias project. The RCN had something to offer for everyone: medical aid for the local Jewish population, Jewish mission to bolster the Scots, an emphatic proIsraeli stance in politics to console the DRC.

\section{Claude Muller-Duvernoy}

In the fifties, the status of Christian Jews in Israel remained unchanged: they were allowed to do whatever they wanted within the boundaries of Christian territory (the milla). As far as Western Christianity was concerned, the State of Israel respected the traditional autonomy of their millets. However, once they left the premises and were recognized as "Jehudim Meschumadiem" (Jewish apostates), Christian Jews were treated as if they carried a contagious disease - especially if they would try to evangelize. 
In contrast, non-Jewish Christian attitudes changed rapidly. Though the Scots and the Dutch officially still tried to attract Jewish "seekers" to their faith, the DCR's main interest had shifted to theological discourse, to reading and discussing the Bible together as Jews and Christian. A remarkable phenomenon, not to be found in the works of John Calvin but very much present in all Protestant denominations in the fifties was "geopiety": ${ }^{8}$ a glorification of the spiritual qualities of the land, relating to the presence of Jesus Christ, but also indebted to contemporary Zionist discourse.

Yet, the co-existence of mission and tentative dialogue remained awkward, at least from a Jewish point of view. A proposal to harmonize these extremes came from a French missionary, sent to Israel by the Swiss Société des Amis d'Israel (SAI). ${ }^{9}$ Claude Muller-Duvernoy wanted to quit with his job. $\mathrm{He}$ was impressed by the DRC programme, but according to him it had not moved far enough. Like the Old, the New Testament was Jewish, explained for Gentile audiences by "the most striking rabbi of all, Saul of Tarsus" ${ }^{10}$ In order to understand their Bible, Protestants needed to learn by listening to Jewish Bible teachers.

Muller-Duvernoy also advocated a renewal of determinism that had characterised Calvinism at its incipit. In his interpretation, this meant that the Jews would eventually accept Jesus as the Messiah, but that there was nothing that Christians could do to influence that event.

As a consequence, he advocated a general withdrawal. He made sure that the message also got through to Germany. The missionaries would have to go:

They hardly know anything about Judaism, and do not even seem interested in learning more about it. (...) What, we may ask, are these missionaries actually doing in Israel? They hang around, enjoy their regular pay, distribute Bibles and silly leaflets, and perform irresponsible baptisms without a second thought for the

8 Cf. Michael Marten, Attempting to bring the gospel home, p. 11.

9 Michaël Cohn, interview Claude Duvernoy, in Nieuw Israëlitisch Weekblad 24 February 1967.

10 Claude Duvernoy, Pour l'Amour de Sion, p. 3. 
consequences. In many cases, the deal is sweetened by the promise of a visa for Canada or Australia.

Only Jewish Christians, in his view, were entitled to preach the gospel to their fellow Jews. ${ }^{11}$ All the other could foster Jewish-Christian relations by engaging in the build-up of the land: working in a kibbutz, a hospital, a school or a factory. The Muller-Duvernoy approach fits well within the reconstruction by Heleen Murre-van den Berg. Western missionary approach in Israel had entered a stage of rapid change: "Introduction and development of education and medical health care were more and more seen as laudable aims in themselves, even when not generating conversions." 12

Muller-Duvernoy became a Christian Zionist, moving towards the insights of American Evangelicalism. He deplored the fact that most of the Protestant Churches in Europe seemed to lose their interest in their Jewish members. That interest remained viable in the United States, though shifting from baptized church members to mostly unbaptized Messianic Jews. In their own way, they were fierce Zionists: "Ces hommes et ces femmes qui ont reconnu et salué en Jésus de Nazareth la personne du Messie et du Seigneur se veulent de fidèles citoyens de l'État d'Israël." ${ }^{\text {"3 }}$ They envisaged a Hebrew Church. There was even a Roman-Catholic equivalent of this idea, the "communauté catholique d'expression hébraïque en Israel."

Muller-Duvernoy hoped that a Hebrew Church would become the prime representative of Protestantism in the State of Israel, supplanting the missionaries of a bygone colonial era. The plan however went awry from the beginning. As events turned out: it was not the Protestants missionaries that were destined to leave. Protestant institutions, like for example the Swedish Institute in Jerusalem, effected a speedy and successful change from mission to dialogue and scientific cooperation, within the span of less than two decades. Not the missionaries but the Jewish Christians were destined to step back: for them, there was no room in the dialogue between Israel and the established churched of the West, as worked out during the early years of the sixties.

11 Claude Muller-Duvernoy, "Ein Jahr in Israel," in Der Freund Israels 1957 nr. 2 (April).

12 Heleen Murre-van den Berg, New faith in ancient lands, p. 15.

13 Claude Muller-Duvernoy, "À la communauté évangélique de langue hébraïque en Terre d'Israël," in La vie Protestante, 7 December 1956. 


\section{5. "Under the heavy cloud of darkness and death"}

After 1948, Israel's socialist Mapai government generally would allow all shades of Protestantism to operate in their respective ways, provided that direct methods of evangelization were limited to the inner sphere of the millet. Many Protestant churches used this relative freedom to operate at different levels in different ways, simultaneously: one level for still ongoing missionary approach, one level for political and economic cooperation, yet another level for dialogue. Jewish Christians were conspicuous in the two formers levels: either employed in traditional missionary work or pursuing private lives: trying to become integrated in Israeli economy as holders of American or European passports. They were not recognized as Jews under the Law of Return ${ }^{14}$, and as a consequence could not apply for Israeli citizenship. On the latter level, that of dialogue, they were strikingly absent.

The cause was a gradual shift in Israeli policies. A tougher stance towards the churches was not only advocated by the religious parties in Israel but also by one of Ben-Gurion's advisors in religious affairs: Raphael Jehuda Zwi Werblowsky of the Hebrew University. He had assisted in the buildup of the Israel-American Institute of Biblical Studies that presented itself as Christian Zionist. ${ }^{15}$ At the same time he found it hard to accept that nations that had been directly involved in the Holocaust - Germany first of all, but also the Netherlands - still could harbour organizations for Jewish Mission.

Werblowsky was also a founder of the Committee for Inter-Faith Understanding in Israel. One of the prime goals of this institution was to gather support for the State of Israel in the Christian Churches in the West. However, now that the Jewish State was becoming consolidated, the time seemed ripe to reconsider the scope for Protestant enterprise. In the early sixties, it was still common practice for the RCN to deliver missionary papers at Jewish addresses in Amsterdam. The Church of Scotland would employ baptized Jews in evangelization in Jerusalem, where the American Mennonites operated a "house of seekers".

14 Colin Shindler, A history of modern Israel, 87.

15 Paul Charles Merkley, Christian Attitudes, pp. 164-165. 
Werblowsky was no longer willing to condone this. He asked representatives of all Protestant denominations in Israel to meet with him in the YMCAbuilding in Jerusalem. The "Jerusalemer interkonfessionelle Aussprache", as Munich-born Shalom Ben-Chorin called it, took place on the 23d of March 1961. Yonah Malachy and Chaim Wardi attended as representatives of the Ministry of Religious Affairs. Werblowsky made it clear: Protestants had no right to expect Israeli willingness to engage in dialogue, as long as they continued their missionary programmes. Shalom Ben-Chorin noted the point:

Dr Werblowsky made it very clear for the ladies and gentlemen of all attending nineteen Protestant churches and missionary societies that the time had come to make up their minds. He was blunt in this. They had to choose, without equivocation, between the options of Jewish-Christian dialogue or Jewish mission. These practices cannot coexist together. ${ }^{16}$

In Jerusalem, traditional mission was still a fact of life, with some very conspicuous Jewish converts as champions of that case. In the West theology was reforming, more research than mission-minded; especially at the level of universities. Werblowsky mentioned some luminaries, such as Karl Barth in Basel, Rudolf Bultmann in Marburg and Paul Tillich in Chicago. Protestantism in Jerusalem seemed backward: not only in the ongoing hope of attracting Jewish "seekers", but also in the idea - naive according to Werblowsky - of the Old Testament being "common heritage" and therefore a suitable topic of conversation between Jews and Christians. Now, the Protestants in Israel, were warned by Werblowsky that they could not have their pie and eat it too. Like all denizens in Israel, they were entitled to the freedom of religion - but not the right to evangelize the very people that were also envisaged as partners in dialogue. "We Israeli expect of Christians, that the tolerance we respect and extend to others, will not be abused in the context of a strategy to make Jewish proselytes". ${ }^{17}$

16 Shalom Ben-Chorin, "Religiöse Ko-Existenz," in Jediot Chadasjot 14 April 1961.

17 Shalom Ben-Chorin, "Religiöse Ko-Existenz," in Jediot Chadasjot 14 April 1961. 


\section{Israel and apartheid - the case of the Jewish Christians}

The debate became connected to contemporary events in South Africa. Werblowsky had made it explicit: a "dialogue of Church and Israel" was only acceptable for Israel, as long as missionaries and Jewish Christians were excluded. Werblowsky explained that "Jehudim Meschumadiem", as he called them, were considered traitors by Israeli society. ${ }^{18}$ As a consequence, any friendly meeting between Church and Israel was not only incompatible with ongoing missionary programmes, but also incompatible with participation of Jewish Christians. If the Christians wanted to meet the Jews in Israel, they would have to leave their Jewish co-religionists out. For Werblowsky, this was a consequence of a decision made by Jewish Christians, as he saw it, to disengage from the Jewish people. In his opinion, they could not simultaneously exchange the people of Israel for the Church, and re-enter the Jewish community by the means of inter religious dialogue.

There was an important appendix: the churches and Christian communities were required to act upon these guidelines as if it were their own decision. Jewish-Christian dialogue, according to Werblowsky, was a Christian desideratum. It was up to the Christians: if they really wanted to meet Israel in dialogue, they would have to leave both their missionaries and their Jewish coreligionists' home.

The Protestants present at that meeting in Jerusalem in 1961 were not unreceptive as to what Werblowsky had to say. As to the Jewish Mission, it was felt that the Israeli had a strong case. Indeed, it was hard to explain to Israeli society how one could try to convert the Jews the one day, only to meet them in dialogue the other day. The case of the Jewish Christians was harder, much harder. The dilemma for the churches was: can we exclude Christians from participation in a dialogue programme, simply because they are of Jewish descent? No, answered the well-known missiologist Johannes Verkuyl of Free University in Amsterdam: to comply with Israeli rules for dialogue would be equivalent to participating in dialogue programmes in South-Africa where black Christians were being excluded. Israel, in Verkuyl's view, stood in the danger of becoming an Apartheid

18 R.J.Z. Werblowsky to J.J. Pilon, Jerusalem 6 February 1962, in Archive Johan Pilon, Haarlem (AJP). 
State, where the Land Promise of the Old Testament was manipulated in order to dispossess the original owners of a contested territory, where Arabs were second-rate citizens and where Jewish Christians were discriminated on ethnic grounds. ${ }^{19}$

And yet, after the Second World War, the impetus in the churches to meet Israel on a new footage, of friendship and dialogue, was very strong in American and European Protestantism. One of the first Christian organizations to act according to Werblowsky's guidelines was the Protestant kibbutz Nes Ammim in the Galilee, supported by the DRC and RCN, together with Protestant churches in Switzerland, America and Germany. The leadership spoke out in 1962: "We will have to accept the consequences, in order to do our work in Israel. The project will aim at a working relation between Jews and Gojim. Jewish Christians belong to a different category, somewhere in between. They cannot take part in this enterprise. We have to make this clear. There can be no place in this settlement for Jewish Christians." "This decision was communicated in the Jerusalem Post in February 1962: "Nes Ammim will not be settled by Jewish converts, although some press reports have mistakenly alleged this." 21

\section{7. "Unequivocal rejection of all Hebrew Christians"}

The main proponents of this decision were the Dutch and German participants. Their argument was that the proposed kibbutz was meant to bring Christians and Jews together. In a project of this kind, in Israeli society, it would not do to bring in participants that most Israelis simply did not want to meet. It was an argument that the American and Swiss participants found hard to swallow:

Nes Ammim has given in, after it had been pressed to the wall. The unequivocal rejection of all Hebrew Christians amounts, in my view, to a betrayal of the unity of the Christian Church. (...) At the moment, I have no prospective Hebrew Christian in mind for the

19 Cf. J.M. Snoek and J. Verkuyl, Intern beraad, pp. 97-98.

20 J.J. Pilon to R. Bakker, F. Kuiper, J.H. Grolle and K.H.E. Gravemeijer, Heemstede 6 februari 1962, in Archive Johan Pilon, Haarlem (AJP).

21 Henriëtte Boas, "Constructive atonement," in Jerusalem Post 19 February 1962. 
membership of the Nes Ammim village. I have no idea whether they are capable of managing an agricultural enterprise. However, it would be cowardly, unfair und un-Christian to shut them out, simply because their descent is Jewish. ${ }^{22}$

The Swiss would accept a "fait accompli": an official ban by Israeli authorities. Unacceptable to them was a policy they were to carry through themselves, as if it were their own decision. "In any case", the Swiss Hans Bernath remarked, "I would defend the principle of never excluding persons or even entire groups, not as long as we aim for positive Christian action". ${ }^{23}$

The Jewish Christian society Hadderech in the Netherlands filed a complaint, accusing Nes Ammim of discrimination on both racist and ideological grounds. This also affected the Dutch Reformed Church (DRC) and the Reformed Churches in the Netherlands (RCN), both of whom were sympathetic to the project. ${ }^{24}$ Hendrikus Berkhof, professor in Leiden and a prominent theologian in the DRC, referred to what he called a "diabolical dilemma". ${ }^{25}$ There was no official ban, and yet: organizations for Jewish Christian dialogue stood no chance when Christian Jews were included, at least in the State of Israel. As this dialogue had been recognized as a goal of prime importance, for instance in the DRC Church Order of 1951, Berkhof grudgingly accepted that there was no way but to comply with Israeli wishes: "In principle, this is impossible. And yet, there is no other solution, be it under protest and for the time being". ${ }^{26}$

Hanna-Louk van Stegeren-Keizer wrote: “To ignore Israeli wishes would bring about the liquidation of dialogue". ${ }^{27}$ Van Stegeren-Keizer was a Jewish member of the RCN, and yet willing to accept the Werblowsky rulings. There were consequences, also for herself: "That Jewish Christians cannot be admitted to Nes Ammim (...). Not only for the time being, as in the case

22 H. Bernath to J.J. Pilon, Nazareth 27 October 1962, in AJP.

23 H. Bernath to J.J. Pilon, Nazareth 22 September 1962, in AJP.

24 J.F.L. Bastiaanse, De Jodenzending, I 550.

25 H. Berkhof, "Nes Ammim als toetssteen", in Kerk en Wêreld March 1966, pp. 36-7.

26 H. Berkhof, "Nes Ammim als toetssteen", in Kerk en Wêreld March 1966, pp. 36-37.

27 Discussion paper by D. Lam and H.L. van Stegeren-Keizer, Heemstede 10 April 1963. Archive H.L. van Stegeren-Keizer, in Historical Documentation Centre of the Free University, Amsterdam (HDC VU). 
of the Germans, but definitively." ${ }^{28}$ Rev H.L. Ellison of the International Hebrew Christian Association (IHCA) was stunned. In his opinion, he had been let down by fellow Christians who had formerly professed to be his "zealous friends":

They have been so skilfully handled by the Israeli authorities that Hebrew Christians must be excluded from the community, if it gets going. Obviously, the Hebrew Christians feel that they have been betrayed, even though few, if any, would have joined the community. On the other hand, the Israeli authorities are more than ever convinced that the Christian Church does not stand behind the Israeli Hebrew Christian and is not really interested in his welfare. ${ }^{29}$

Maas Boertien, of the Christian Reformed Churches (CRC) added an explicit reference to Apartheid in South Africa:

Under pressure of the Israeli government and/or the Jewish public opinion, Nes Ammin has agreed to a policy of "apartheid". (...) In order to get the necessary permission to build their settlement, NA has sacrificed its Christian character on the altar of Jewish nationalism. ${ }^{30}$

His analysis of events was as follows:

In the opinion of the Zionists, the greatest sin for a Jew is "assimilation"; a Jew's membership of a Christian Church is supposed to be assimilation "par excellence", as in the Zionist opinion (and Jewish opinion in general) such a membership involves a denial of the special call of the Jew (whatever that call may be; opinions differ widely on this).

The Israeli Jewish press called NA a missionary enterprise, and either from a Jewish-religious or from a nationalistic point of view (as a rule both are combined) such an enterprise was supposed to be

28 J.J. Pilon to S. Bezek, Heemstede 8 April 1963, in Archive Johan Pilon, Haarlem (AJP).

29 H.L. Ellison, editorial comment, in The Hebrew Christian October 1963, p. 74.

30 M. Boertien to M.C. King (Genève), Jerusalem 30 July 1964, in Archive Nes Ammim Netherlands (ANAN). 
very dangerous. In order to "save" the project, the Dutch leaders of NA gave in to pressure, and agreed to the following conditions:

(a) NA will not engage in missionary activities;

(b) Hebrew Christians cannot become members of the settlement.

Condition a) was imposed by the Israel government (...). Whether condition b) was imposed by the Israel government or whether NA itself "voluntarily" (i.e. under pressure of the Israeli Jewish public opinion) declared this, is not known to me. Repeatedly I begged the Dutch board of NA to show me a copy of the minutes (...) but I never saw copies of such official documents. It is, however, clear from statements made by NA that their settlement will not accept Hebrew Christians.

This is, as far as I can see, the crucial point where NA deviates so far from their original set-up that, unless NA will change this policy openly and immediately, no Church or Christian agency would sponsor this "Christian" settlement. ${ }^{31}$

A defence of the decision to exclude Jewish Christians came from Germany. Theologian Heinz Kremers of the German Evangelical Church emphasized the guilt of his nation during the Hitler regime. For him, Jewish Christiandialogue was not so much an option as a self-evident necessity. Kremers published Das Verhältnis der Kirche zu Israel in 1965. Christianity was an offspring from Judaism. The first disciples of Christ never harboured any intention of leaving the Jewish fold. For Kremers, the conclusion was clear: Jewish followers of Jesus belonged in Judaism, not in the church or in church organizations. In the opinion of Kremers, this was not discrimination or apartheid. "The Jewish Christian of the earliest church ever remained a Jew. However, a baptized Jew in our days renounces Jewish identity from the moment he accepts baptism. This very fact is shaming. It is the greatest guilt in the history of the Church, during ages of Jewish Mission between the fourth century (Constantine) and the present time. Organizations like Hadderech and IHCA were simply bad for their own members, they drove them into a dead-end alley: "As we, heathen Christians, forced our principles of Christianity upon the Jewish Christians, we deluded them.

31 M. Boertien to M.C. King (Genève) and others, Jerusalem 30 July 1964, in ANAN. 
(...) We cut them off from the organic unity of the people of Israel, elected by God to remain both a chosen people and an abiding faith community forever." 32

The "working committee of Jews and Christians, related to the Kirchentagforum of the German Evangelical Church Arbeitsgemeinschaft Juden und Christen beim Deutschen Evangelischen Kirchentag" almost fell apart on this issue in 1963. The German rabbi Robert Raphael Geis ${ }^{33}$ mentored his Christian pupil Heinz Kremers. ${ }^{34}$ Geis would have nothing to do with the "revised Jewish mission, perpetrated under the guise of dialogue." Jewish Christians were in the front of this missionary drive. They could not be accepted, least of all in a dialogue in which Israel could decide for itself whether it wished to take part or not:

If witness to the presence of Jesus Christ, whatever form it may take, implies the idea that the Jewish will convert to the Christian Messiah at the end of days, then this same witness doubts or even violates the intrinsic value of Jewish witness. As to us Jews, we consider this approach as simply unacceptable, for obvious reasons. ${ }^{35}$

\section{Evaluation}

The tenets of Kremers and Geis were accepted in the end, at least by the Church and Israeli programmes in the DRC and RCN in the Netherlands, and the Rheinische Kirche in Germany. What we find here is a paradox. During the sixties of the twentieth century all of these churches became opposed to discrimination, racism and apartheid policies. At the same time, in the State of Israel and in the aftermath of the Shoah, they could not and would not avoid the exclusion of some of their members from a programme of Jewish-Christian dialogue. This exclusion was not only based on the convictions and actions of those concerned, but also on their

32 Kurzmemorandum über Sinn und Aufgabe einer christlichen Siedlung in Israel (1964), in Archive Nes Ammim Galilee (ANAG).

33 R.R. Geis, "Judenmission," pp. 242-247.

34 R.R. Geis to Adolf Freudenberg, Düsseldorf 6 September 1963, in Leiden an der Unerlöstheit der Welt, p. 230.

35 R.R. Geis to H. Gollwitzer, Düsseldorf 18 and 23 March 1964, in idem, pp. 252-253 and 259. 
ethnic background. Interfaith dialogue after the Holocaust clashed with accepted standards of non-discrimination. The sensitivity of this subject is obvious, even today. It is interesting to note that, when delegates to the General Council of the World Communion of Reformed Churches had to cast their votes on a resolution in respect of Israel and Palestine, all the Dutch and German churches abstained (2017).

\section{Bibliography}

Bastiaanse, J.F.L. Bastiaanse, De Jodenzending en de eerste decennia van de Hervormde Raad voor Kerk en Israël. Een generatie in dienst van de Joods-Christelijke toenadering (Zoetermeer: Boekencentrum, 1995).

Duvernoy, Claude, Pour l'Amour de Sion (Jerusalem: Yanetz, 1970).

Elderen, R.J. van, Toekomst voor Israël. Een theologie-historisch onderzoek naar de visie op de bekering der joden en de toekomst van Israël bij Engelse protestanten in de periode 1547-1670, tegen de achtergrond van hun eschatologie (Mondiss: Kampen, 1992).

Faber, G.S., A general and connected view of the prophecies, relative to the conversion, restauration, Union and future glory of the Houses of Judah and Israel (London: Andrews and Wait, 1809). Finch, H., The World's Great Restauration, or the Calling of the Jews, and with them of all the Nations and Kingdomes of the Earth, to the Faith of Christ (London: Griffin, 1621).

Geis, R.R., "Judenmission. Eine Purimbetrachtung zur Woche der Brüderlichkeit”, in Dietrich Goldschmidt en Ingrid Ueberschär (ed.), Leiden an der Unerlöstheit der Welt. Robert Raphael Geis 1906-972. Briefe, Reden, Aufsätze (München: Kaiser, 1984), 242-247.

Gilbert, Martin, Israel. A history (London: Harper Collins, 2008).

Livingstone, W.P., A Galilee doctor, being a sketch of the career of Dr D.W. Torrance of Tiberias (London: Hodder and Stoughton, ca. 1925).

Marten, Michael, Attempting to bring the gospel home. Scottish missions to Palestine, 1839-1917 (London/New York: Palgrave Macmillan 2006). 
Merkley, Paul Charles, Christian Attitudes towards the State of Israel (Montreal: Mac Gill Queen's University Press, 2001).

Murre - van den Berg, Heleen (ed.), New faith in ancient lands. Western missions in the Middle East in the nineteenth and early twentieth centuries (Leiden/Boston: Brill, 2006).

Oostkamp, J.A., De merkwaardigste Bijbelsche Land-en Zeereizen. Een leesboek voor de jeugd (Amsterdam: Beyerinck and Suringar, 1833).

Sand, S., The invention of the Land of Israel. From Holy Land to Homeland (London/New York: Verso Books, 2012).

Shindler, Colin, A history of modern Israel (Cambridge: University Press 2008).

Snoek, J.M. and J. Verkuyl, Intern beraad in verband met de relatie tussen Kerk en Israël (Kampen: Kok, 1988).

Zickermann, E., "Evangelische Liebesarbeit”, in Palästinische Kulturbilder. Beiträge zur Palästinakunde (Deutscher Verein zur Erforschung Palästinas: Leipzig, 1907).

\section{Sources}

Archive Johan Pilon, Haarlem (AJP)

Archive H.L. van Stegeren-Keizer (in Historical Documentation Centre of the Free University, Amsterdam).

Archive Nes Ammim Galilee (ANAG)

Archive Nes Ammim Netherlands (ANAN)

Der Freund Israels (in Zürcher Lehrhaus)

La Vie Protestante (in AJP)

Jediot Chadashot (in scrapbook ANAG)

Jerusalem Post (in scrapbook ANAG)

Kerk en Wêreld (in PThU, Amsterdam)

Nieuw Israëlitisch Weekblad (in KB The Hague)

The Hebrew Christian (in scrapbook ANAG) 